\title{
A ruína do consenso: a política exterior do Brasil no governo Figueiredo (de 1979 a 1985)
}

\author{
The collapse of consensus - the Brazilian foreign policy under \\ Figueiredo (from 1979 to 1985)
}

TÚLIO SÉRGIO HENRIQUES FERREIRA*

Rev. Bras. Polít. Int. 49 (2): 119-136 [2006]

\section{Introdução}

O governo do general João Baptista de Oliveira Figueiredo (1979-1985) foi o último do ciclo militar instalado em 1964. A política externa de sua gestão ficou conhecida, por parte da Historiografia, como Universalismo. No entanto, apesar de ser formulada e implementada naquele período, não era a única matriz que pensava o posicionamento do Brasil no mundo. Houve claras manifestaçóes de descontentamento em relação aos seus pressupostos, podendose identificar explícito grupo de arautos do dissenso. Neste sentido, analisar e demonstrar a ruína do consenso da política externa neste período foi o trabalho deste artigo.

Após balanço historiográfico, evidenciou-se a concentração de estudos que privilegiam fatores políticos, econômicos e geopolíticos, em detrimento das variáveis subjetivas que impactam na formulação da política externa. Neste sentido, utilizaram-se argumentos que defendem abordagens complementares na análise da política externa, sobrelevando-se a importância das percepçôes dos policymakers, momento que antecede a tomada de decisão (SILVA, 1995, p.1).

Sob tal inspiração, contextualizou-se o governo Figueiredo face ao processo de redemocratização e aos novos arranjos de poder político, econômico e social do período. No âmbito político, o país entrava na reta final do processo de liberalização e de retorno do poder às mãos dos civis - período de ricas transformações nas estruturas decisórias do país. Na dimensão econômica, abalos na conjuntura internacional trariam fortes constrangimentos à economia nacional, impondo limites ao projeto de desenvolvimento do país. Neste

\footnotetext{
* Professor do Departamento de Relaçóes Internacionais da Pontifícia Universidade Católica de Minas Gerais - PUC-Minas e mestre em Relaçôes Internacionais pela Universidade de Brasília - UnB (tulioferreira@gmail.com).
} 
contexto, a política externa ressaltou sua característica universalista, respondendo ao cerceamento dos mercados financeiro e comercial. Foi produzido discurso diplomático que reivindicou a democratização do quadro institucional internacional para reverter o fechamento do processo decisório concentrado nas grandes potências internacionais.

O processo de formulação da política externa brasileira é estudado para entender as matrizes de pensamento que teorizavam sobre o papel a ser desempenhado pelo Brasil no ambiente internacional. São expostas as bases da Política Externa Universalista, assim como as idéias contrárias a essa concepção. As manifestações dissonantes relativas à política externa conduzida pelo chanceler Ramiro Saraiva Guerreiro emanavam em conjuntura marcada por grave crise econômica e por forte movimentação dos setores da sociedade que lutavam pelo poder. Fatos que afetaram o processo decisório do Estado brasileiro. Portanto, reforçou-se a necessidade de teoria que conceba o Estado como permeável às demandas de seu tecido social, sendo o 'Interesse Nacional' resultante do equacionamento das vontades dos diversos setores constitutivos da Nação (PINHEIRO, 1994).

\section{Visões do Brasil no mundo}

Um ponto de partida para que se percebam as diferentes visões de mundo vigentes na gestão Figueiredo é indagar pela concepção militar de inserção externa do país. Teixeira (2002) argumenta que, apesar da dificuldade de se buscarem tais pressupostos empiricamente, é fato que tenha se formado razoável consenso entre os militares acerca da importância da construção de um status de potência para o país. Tal concepção encerrava a expectativa de que o Brasil pudesse alcançar os níveis superiores da hierarquia internacional. Para tanto, a capacidade de defesa dos interesses nacionais além fronteira era imprescindível, o que somente seria alcançado mediante o desenvolvimento econômico e a construção do espaço de autonomia nacional. Neste sentido, a busca de mercados não tradicionais e mesmo contrapostos ideologicamente aos pressupostos do Estado autoritário estaria justificada pela prioridade de se conseguir insumos ao desenvolvimento.

No entanto, os limites impostos pela conjuntura ao modelo nacional desenvolvimentista trariam seus desdobramentos na política externa brasileira. Cervo e Bueno consideram que o desenvolvimento, mesmo tendo permanecido como objetivo a ser perseguido, perde força com a redução de eficiência da estratégia posta em curso pelos militares. "É nesse contexto extremamente adverso que a diplomacia brasileira tentou formular uma política externa de cunho universalista, buscando reavivar o multilateralismo como forma de tentar superar a crise" (2001, p.46). 
A lógica ecumênica implicava a continuidade do modelo desenvolvimentista por meio da busca de fontes alternativas de conexões internacionais. Assim, a aproximação com a América Latina, África, Ásia e Oriente Médio, além da busca de diálogo com os paises socialistas da Europa Oriental decorriam dessa visão. O projeto universalista torna-se um plano de inserção planetário, expondo o país a diversas formas de relações internacionais. Neste sentido, argumentase que Figueiredo continuaria, e mesmo aprofundaria, a política exterior de Geisel, devido à impossibilidade de se efetivarem rupturas drásticas com o modelo em curso (CERVO e BUENO, 2001, p. 47).

Azeredo da Silveira, chanceler no governo Geisel, demonstrava preocupação com a manutenção das linhas básicas da política externa que ele havia implementado. Ele considerava que, naquele período, viveram-se "tempos de decisões difíceis com o reatamento com a China, a investida comercial na África e Ásia, o abandono da dependência econômica em relação aos Estados Unidos" (ISTO É, 3.1.1979, In: TEIXEIRA, 2002, p. 48). Neste sentido, a escolha de Guerreiro para chanceler do governo Figueiredo reapresentou a vitória na luta pela manutenção da política externa exercida por Silveira.

No entanto, ao se observar a movimentação para a escolha do chanceler de Figueiredo, fica evidente que não havia somente uma linha de pensamento acerca dos rumos que o país deveria tomar. Roberto de Oliveira Campos registra em suas memórias que, em fins de 78 , seu nome teria aparecido como 'ministeriável' nos jornais. O então embaixador em Londres aponta que o processo da escolha do chanceler para o governo Figueiredo teve forte componente ideológico. Assim, ele teria sido preterido devido ao seu posicionamento crítico em relação ao Universalismo. Ele narra:

A única posição que me interessaria seria o ministério do Exterior, por ser coroamento da carreira e porque a política externa terceiro-mundista precisava de uma 'chacoalhada'. Considerava, entretanto, algo humilhante oferecer-me para o cargo e por isso não me dispunha a ir ao Brasil. Pressentia, aliás, que meu nome encontraria forte oposição, particularmente do chanceler Silveira, que desejava continuar no cargo ou, pelo menos, 'fazer' seu sucessor. Isso foi facilitado pela coincidência de que o general Medeiros, que sucedera a Figueiredo no SNI, tinha como candidato seu concunhado, o embaixador Saraiva Guerreiro, então embaixador em Paris, que fazia parte da 'igrejinha' do Silveira (CAMPOS, 1994, p.1013).

Por seu turno, Guerreiro faz suas considerações acerca das razôes de sua escolha para o mais alto cargo das relações exteriores do país.

Fui convidado pelo presidente eleito a assumir a função de ministro de Estado das Relaçôes Exteriores. Na ocasião, sua excelência me disse, inter alia, que me conhecia mais do que eu supunha e desejava prosseguir, com as adaptaçôes aconselháveis, na política externa do governo anterior. $\mathrm{O}$ fato de haver sido secretário geral e estar 
intimamente ligado, por ofício, à execução dessa política, evidentemente teria pesado, entre outros fatores, que não caberia destacar aqui. Embora estivesse de acordo com meu chefe com a linha geral de uma política que se denominava de PRAGMATISMO RESPONSÁVEL, como Ministro, creio não haver usado a expressão mais do que uma vez, e ainda no princípio. Não tinha objeção de substância, mas, até por temperamento, me parecia que podia prestar-se a equívoco (GUERREIRO, 1992, p.27).

Assim, observa-se a vontade manutenção dos vetores básicos da política exterior pragmática do Brasil. No entanto, o quadro conjuntural nacional e internacional era diverso. Os formuladores daquela política deveriam ler um mundo complexo e propor ações. O Universalismo acaba por encarnar forte dose de contradições. Teixeira (2002, p.51) observa que o Brasil, naquele período, de fato apresentou uma postura externa ambivalente em suas relações norte/sul e sul/sul. Assim, simultaneamente à busca de integração com os países do Terceiro Mundo, o Brasil também queria inserir-se no Ocidente desenvolvido, compartilhando seus valores. Sennes (apud TEIXEIRA, 2002, p.52) teoriza que países intermediários (como o Brasil), recém industrializados, oscilam entre atitudes com característica de país forte e fraco. Assim, sendo ora autônomos, ora dependentes, acabam estabelecendo formas compostas de atuação internacional.

No entanto, apesar da manifesta 'dubiedade' na PEB, o Estado ainda concebia tal política como necessariamente reflexo de um consenso nacional a apontar o rumo do país no ambiente internacional.

\section{A busca do consenso}

No governo Figueiredo, a unidade de princípios era apontada como necessária ao bom andamento da política externa do país. Defendia-se que "a confiabilidade da política externa de uma potência intermediária exige, além de um adequado relacionamento diplomático e da coerência, a solidez de um consenso interno" (LAFER, 1983, p.19). Assim, a capacidade de gerar, incorporar e refletir consensos era considerada essencial ao governo.

Tal característica tomava proporções específicas por ser o governo comandado por regime militar que, através da ideologia da segurança nacional, impunha a unidade da nação e o patriotismo exacerbado. Milza considera que a busca do consenso pela política externa, objetivando integrar as massas e superar as ideologias antagônicas das lutas partidárias, pode levar o grupo dirigente de um país a propor projetos mobilizadores cujo principal objetivo seria preservar a unidade da nação ameaçada pelas forças centrífugas do dissenso (MILZA, 1996, p.380).

Reflete Debrum (1983, p.15) que a necessidade de consenso na política externa propagada pelo regime militar pode ser vista como uma parte do amplo 
universo da política nacional, já que a conciliação faz parte da tradição política brasileira. Mas, ele deixa claro que a conciliação existente no Brasil não é aquela que pressupõe atores com os mesmos recursos de poder, impossibilitando que um ator esmagasse o outro. De modo diverso, no Brasil, a conciliação sempre pressupôs assimetria entre os atores, em uma palavra: desequilíbrio. Portanto, o consenso serviria para reforçar o poder daqueles que já o detinham, ou mesmo para propor "a todos ou apenas aos setores potencialmente dinâmicos da sociedade, projetos nacionais - de redenção, de desenvolvimento, de Pátria Grande etc. - em torno dos quais deveriam congregar-se as vontades" (DEBRUM, 1983, p.13).

A política externa estava em sintonia com tais preceitos. Guerreiro, em sua última visita à ESG, discursa em tom analítico e retrospectivo a sua gestão. "Procuramos fazer que a atividade diplomática sirva de ponto de união de brasileiros, de coesão política e social, e não a interesses localizados e transitórios" (RESENHA, ED.SUPL. 1984, p.68). Ao considerar assim o papel diplomático, ele fará, em outro ponto, a defesa do necessário consenso e a desqualificação dos eventuais críticos.

Creio que a condição do prestígio diplomático foi plenamente alcançada no período. Vejo sinais claros, e um dos mais significativos é o consenso que se forma em torno das linhas mestras da política externa, tanto na opinião pública quando em nossos meios políticos. Um dos elementos expressivos desse consenso é o apoio, praticamente unânime, das correntes políticas às orientações centrais do trabalho diplomático. Houve criticas, em regra torneadas por sinceras preocupaçôes. Respeitamo-las invariavelmente, mas ficam, em sua maioria, restritas ao círculo de expressão limitada. Não acredito que tenham criado raízes sólidas. Para um país que não tem excedente de poder, o consenso e unidade na defesa do interesse nacional se tornam a sua força. A unidade moral de propósitos - não imposta, mas tecida democraticamente - é matriz sólida e realização de nossos objetivos (IDEM, p.79).

Acredita Przeworski (1994, p.107) que nos arranjos burocráticoautoritários o dissenso encontra alguns limites, mesmo que não possa ser totalmente impedido. Ele identifica um fato comum às ditaduras: elas não podem tolerar organizaçôes independentes, pois enquanto não houver alternativas disponíveis em termos coletivos, as ações individuais não adquirem importância significativa para o governo. Assim, o que ameaça o regime autoritário não seria tanto a quebra da legitimidade, mas a organização de projetos contra-hegemônicos que se estabelecessem como alternativa para o futuro.

O Estado Burocrático Autoritário (EBA) concebia o Itamaraty como uma instituição que deveria ter idéias coerentes e autônomas que minimizassem o conflito e a competição para o interior da organização (CASTRO e SANTOS, 1988, p.70). A vontade de coerência também se aplica para a constituição de 
uma linha unívoca de percepção do papel que a nação deveria ter no sistema internacional. Portanto, as considerações relativas ao papel do Brasil no cenário internacional criadas e defendidas pelo Itamaraty eram fundamentais, pois as escolhas dos formuladores de políticas são feitas com base no 'estoque' de paradigmas que concebem a imagem do país e o lugar que este deve ocupar no mundo (SILVA, 1995). Portanto, minimizar os contrastes existentes entre paradigmas que coabitavam a instituição seria a política óbvia de um regime que pregava a união. No entanto, o sucesso dessa empreitada parecia improvável dada a conjuntura em que se enreda o governo do último general presidente do ciclo ditatorial de 1964.

\section{Dissonâncias}

O Universalismo, apesar de ser o projeto posto em prática, não era o único. A existência de dissonâncias relativas à melhor inserção internacional do Brasil pode ser depreendida tanto nos discursos oficiais como em artigos e entrevistas de atores da vida política e econômica nacional. O consenso pregado pelos formuladores da política externa havia perdido intensidade em decorrência da forte crise estrutural por que passava o país. Mesmo assim, Guerreiro (RESENHA, ED.SUPL., 1984, p. 86) defendia que a atividade diplomática deveria servir "de ponto de união de brasileiros, de coesão política e social, e não a interesses localizados e transitórios".

Porém, tal discurso é contrastado por outras falas que acabam por explicitar as indesejáveis divisões. $\mathrm{Na}$ verdade, o próprio chanceler estava ciente da maior complexidade que o panorama político da abertura traria ao equacionamento das pressōes dos diversos setores sociais. Em seu primeiro pronunciamento na ESG, em 13 de julho de 1979, Guerreiro reconhecia que o novo quadro nacional e internacional traria novos desafios à sua gestão. Em sua visão, a redemocratização que vinha sendo efetivada na gestão Figueiredo trazia implicações evidentes para a política externa. Ponderava que a despeito da ação diplomática brasileira sempre ter procurado formas de ação que transcendessem as conjunturas partidárias, fixando o interesse nacional consoante com o conjunto da nação, o dissenso era inevitável. Porém, defendia que mais forte seria o consenso relativo aos anseios da nação, se tal fosse conseguido em um quadro de amplas franquias democráticas.

Por isso, o Itamaraty, como instituição, está certo de que a abertura política servirá com proveito à política externa. Estamos preparados para aceitar o debate sobre política externa, debate esse que, de uma forma ou de outra, sempre existiu. Tenho a certeza de que com o debate, não haverá abalo na confiança que a nação deposita em sua política externa. Faço questão, também, de indicar que não é esta uma atitude retórica. Ao contrário, a capacidade de resposta democrática, de aceitação das propostas que 
visem consistentemente ao interesse nacional, a ponderação de sugestões deve fazer parte do metabolismo institucional do Itamaraty. É nosso instrumento de participação democrática no Brasil (RESENHA, ED. SUPL., 1984, p.13).

Cervo (RBPI, 2003, 46/2, p.13) acredita que, por décadas, a ideologia desenvolvimentista fez a unanimidade no Brasil, mas não fez a unidade do entendimento político. Intelectuais e dirigentes, além da opinião pública, estariam divididos em torno do modelo a colocar em prática. Ele identifica a formação de duas correntes: uma do desenvolvimento associado com a prevalência das relaçôes políticas econômicas e geopolíticas com a matriz do sistema (EUA) e outra do desenvolvimento autônomo, baseado nas forças da nação, que buscava autonomia política e a formação de forte núcleo econômico interno. Este último projeto encontraria fortes obstáculos ao se intensificarem os vetores de interdependência global, trazendo limites ao projeto desenvolvimentista dos últimos governos militares. Cervo continua o raciocínio defendendo que as duas propostas estratégicas não declarariam guerra entre si, como observado na Argentina. De modo diverso, ele acredita que por meio do diálogo entre as duas correntes resultou um modelo misto de desenvolvimento que tomou longo fôlego para ser utilizado de modo racional em doses equilibradas.

Jose Honório Rodrigues, em Interesse Nacional e Politica Externa, escrito em 1966, já apontava duas matrizes a serem identificadas no longo curso. Uma pregava desenvolvimento independente, outra interdependente. Portanto, ao se analisar o governo Figueiredo, entende-se que as concepções de política externa em curso não eram idéias apenas conjunturais, mas representavam a retomada de algumas matrizes de pensamento que encontram momento e oportunidade de afloramento.

Conforme se observam os fatos da política brasileira no governo Figueiredo, percebe-se que houve relativa aceitação do projeto Universalista até 1982. Guerreiro (1991, p.13) admite que as críticas aparecem com mais vigor em meados de 1982. No entanto, em suas memórias, ele registra que "desde o meu primeiro ano de ministrança, havia quem não gostasse quando incluíamos o Brasil no Terceiro Mundo.” Dentre os descontentes com tal posição estava o embaixador Campos que propunha uma 'chacoalhada' na política externa terceiro-mundista.

Campos recorda (1999, p. 1014) que no calor da 'batalha' para a escolha do futuro chanceler, ele produziu um memorando interno com recomendaçôes de ação para que o Brasil se adequasse aos novos tempos. Em 'As Novas Perspectivas da Política Exterior' ele analisou as transformaçóes do mundo e os impactos conseqüentes em uma potência emergente como o Brasil. Haveria algumas opções para a política externa, dentre elas o 'NEUTRALISMO', o 'TERCEIRO-MUNDISMO', o 'ALINHAMENTO AUTOMÁTICO' e a 
'PARCERIA SELETIVA'. Em sua concepção, somente a última era cabível ao Brasil que se inseria em um contexto marcado por "relativo enfraquecimento da liderança político-ocidental; pela politização do problema energético; pelo recrudescimento do terrorismo; pela mutação das formas de soberania e pelo neoprotecionismo".

O interessante memorando interno, endereçado a Silveira (chanceler do governo Geisel), era sua exposição de motivos para a formulação de política externa que adequasse o país ao novo quadro de desafios que a conjuntura internacional impunha. $\mathrm{O}$ documento passa em revista aos principais temas das relações internacionais dos anos 70 e propóe muitas ações diversas daquelas em curso. Inicialmente, Campos (NPPEB, 1978, p.i.) identifica um fato e propõe dois enfoques para a política externa brasileira. $\mathrm{O}$ fato é a maioridade do Brasil como potência de primeiro plano e os enfoques são o econômico e o geopolíticomilitar. Em sua visão, o Brasil estava irremediavelmente lançado ao mundo e seus perigos. Portanto, ter mecanismos para perceber a conjuntura internacional seria fundamental ao projeto da nação. Mas, infelizmente, ele observa que o Itamaraty estava ausente e despreparado para auscultar o mundo e incapaz de tomar decisões acertadas. $\mathrm{O}$ embaixador chega a declarar que não seria exagerado dizer que o Brasil desenvolveu certa tendência a fracionar o seu sistema político e econômico. Assim, aos poucos, o ministério do Exterior foi ficando isolado, um tanto seccionado da realidade mais imediata do país (idem, p. iii).

Portanto, deveria haver modificação estrutural que recompusesse o seu poder e coordenação no processo decisório do Estado. Haveria novas exigências às estruturas no ministério para que ele tomasse parte no processo de planejamento e análise econômica. Em uma palavra, reclamava maior integração no processo decisório, de modo a não marginalizar o Itamaraty das grandes decisões da nação. Campos ainda alertava que, se tal movimento de adequação não fosse feito, o país entraria em dissonância com o resto do mundo.

Seguindo esta linha de raciocínio, ele passa à identificação dos modelos de política externa do Brasil. Veja-se o trecho abaixo que, a despeito da extensão, vale pela síntese que abriga.

\section{ALGUMAS OPÇŌES GERAIS DA POLÍTICA EXTERNA}

5.1. Em termos muito genéricos, indo, por assim dizer, da esquerda para a direita, os diferentes tipos de opçóes abertas a um país como o Brasil poderiam ser consideradas nas quatro seguintes variantes:

i. neutralismo

ii. terceiro-mundismo

iii. parceria seletiva

iv. alinhamento político prévio e automático

(1) As variantes i e ii estariam não apenas fora das tradiçôes brasileiras, mas igualmente fora de uma faixa otimizante dos interesses nacionais, como se infere do que se 
tem visto até este ponto. A variante iv não aberraria tanto da nossa linha histórica, mas teria uma rigidez desnecessária e não se poderia considerar otimizante nas condiçôes atuais.

(2) $\quad \cdots$

(3) No caso brasileiro, a tradição e o que poderíamos chamar de fidelidade histórica coincide com os grandes interesses do país, que se situam no âmbito do subsistema Ocidental. Não haveria, porém, nenhuma razão para que o Brasil abdique do seu lugar na poliarquia, ou simplesmente posponha o seu ingresso nela. Pelo contrário, como foi visto a propósito da posição norte-americana, uma participação decisória mais ativa do Brasil contribuiria para um efeito estabilizador que se afigura cada vez mais urgente.

(4) A variante da parceria seletiva não é nem excludente nem apenas pragmática, com sacrifício de posiçōes de princípio que podem ser requeridas no devido momento. Ela implica, porém, numa clara ênfase sobre o termo parceria, em contraste com a idéia de alinhamento (CAMPOS, NPPEB, 1979, p.17).

A gênese da defesa da 'Parceria Seletiva' está no governo Castelo Branco. Segundo Campos, o marechal teve a oportunidade de reorientar a política externa brasileira que havia oscilado entre

a estratégia da pirraça de Jânio Quadros e os malabarismos intelectuais da política de independência de Afonso Arinos e San Tiago Dantas. No caso de Jânio Quadros, a intenção parecia ser ganhar espaço para uma política conservadora interna no campo econômico, através da exibição de machismo na política externa. No caso de Afonso Arinos e San Tiago Dantas, as proposiçóes eram algo mais sofisticadas. Tratava-se de valorizar o espaço de manobra que nos era dado pelo impasse da bipolaridade (CAMPOS, 1999, p.743).

O próprio general Castelo Branco, ao paraninfar a turma dos formando do Itamaraty, em 31 de julho de 64, esclareceu alguns dos pontos centrais do que Campos, posteriormente, definiu como política de 'Parcerias Seletivas'.

No caso brasileiro, a política externa não pode esquecer que fizemos uma opção básica, que se traduz na fidelidade cultural e política ao sistema democrático ocidental. Dentro dessa condicionante geral, a nossa independência se manifestará na aferição de cada problema específico, estritamente em termos de interesse nacional, com margem de aproximação comercial, técnica e financeira, com países socialistas, desde que esses não procurem invalidar nossa opção básica (in: CAMPOS, 1999, p. 746).

Segundo Campos, caracterizar a política externa de Castelo Branco como sendo de alinhamento automático (como faziam Silveira e Guerreiro) era descabido, pois o marechal havia, preventivamente, rebatido futuras e eventuais críticas. 
Não devemos pautar nossa atitude nem por maquiavelismo matuto, nem por uma política de extorsão. Reciprocamente, não devemos dar adesão prévia às atitudes de qualquer das grandes potências - nem mesmo às potências guardiãs do mundo ocidental, pois que, na política externa destas, é necessário distinguir os interesses básicos da preservação do sistema ocidental dos interesses específicos de uma grande potência. Em resumo, a política exterior é independente no sentido de que independente deve ser a política de um país soberano. Política exterior independente, num mundo que se caracteriza cada vez mais pela interdependência dos problemas e dos interesses significa que o Brasil deve ter seu próprio pensamento e sua própria ação. Esse pensamento e essa ação não serão subordinados a nenhum interesse estranho ao Brasil (in: CAMPOS, 1999, p.746).

Outras críticas são feitas ao Universalismo. Campos (1999, p. 746) apontava constantes demonstrações de indeterminação em certos dilemas como: nacionalismo versus interdependência; negociação bilateral versus negociação multilateral; socialismo versus livre iniciativa. Também, considerava a teoria dos 'círculos concêntricos' mais apropriada à política externa do país. Segundo ele, tal teoria deveria informar as prioridades em nossas relações com as nações irmãs. Neste sentido, deveriam ser prioritárias nossas relações como nossos vizinhos latino-americanos, com os Estados Unidos, com Portugal, com os países africanos do Atlântico e a comunidade européia. No âmbito econômico, seriam prioritárias nossas relações com Estados Unidos, Alemanha e Japão. Tal argumento criticava a ingenuidade do terceiro-mundismo que financiava muitos países somente pelo fato de terem voto na ONU. Também, considerava-se a idéia de Terceiro Mundo uma falácia, pois essa 'entidade' não passava de um 'mosaico incongruente'.

Campos (1999, p. 873) considerava que a proliferação de embaixadas no Terceiro Mundo, principalmente na África, foi um equívoco financeiro, pois o Brasil teria conseguido melhores resultados, com efeitos mais duradouros, se tivesse criado um bom programa de bolsa de estudos e intercâmbio com os africanos. $\mathrm{O}$ embaixador também não poupava de críticas a simpatia que a matriz terceiro-mundista nutria pelo grupo dos países não alinhados (denominados por ele como 'Desalinhados'), pois os líderes Nehru, Sukarno, Nasser, Nkrumah e Fidel Castro haviam conseguido, em curto prazo, a façanha de arruinar seus respectivos países.

O embaixador José Osvaldo de Meira Penna (DIGESTO, 1982, abril, p. 109) foi outro crítico do Universalismo. Em fevereiro de 1982, ele fez contundente ataque àquela Política Externa. Ao discursar na reunião do Centro e Estudos Sociais e Políticos, ele contestou aqueles que culpavam os países desenvolvidos pelo subdesenvolvimento brasileiro, pois a responsabilidade deveria ser atribuída às elites daqueles países que aplicavam políticas restritivas ao desenvolvimento. Segundo Penna, culpar outros países pelas mazelas internas era escapismo. Ele acaba por propor um slogan que, contraditoriamente, relembra os tempos da nacionalização do petróleo no Brasil: O Problema é Nosso! 
Penna (In: DIGESTO, 1982, abril, p. 110) avança sua discordância com o terceiro-mundismo considerando que ele seria uma espécie de tradução moderna do Marxismo clássico que considerava os países 'sub' e 'em desenvolvimento' como o proletariado internacional. No que se refere à política externa, a práxis revolucionária ditava a reunião do Terceiro Mundo contra o imperialismo dos países desenvolvidos, pregando até a guerrilha e o terrorismo. Penna combatia a aproximação com parceiros que pregavam a destruição do desenvolvimento capitalista, pois no centro do poder mundial estavam os melhores índices de equilíbrio social e prosperidade econômica. O Brasil deveria, consequentemente, aproximar-se de modo mais íntimo com o centro do poder e não solidarizar-se com a periferia dependente. De modo irônico ele conclui: "Enfim, retomando a fórmula pascaliana, diríamos que o terceiromundismo tem razões que a Razão desconhece."

Penna apresenta suas restrições à aproximação do Brasil com o chamado Segundo Mundo, por achá-lo ideologicamente e moralmente questionável. Ele define a política externa de Figueiredo como sendo de solidariedade com o Terceiro Mundo, de silêncio em relação às questionáveis atitudes do Segundo Mundo e de reivindicações e ressentimentos em relação ao Primeiro Mundo. Em suma, uma postura nacional-socialista que acabava com definir atitudes equivocadas do Brasil para a conjuntura internacional da primeira metade dos 1980 (DIGESTO, 1982, abril, p. 115).

Tal posicionamento resultaria de sua frontal contraposição aos resquícios da Política Externa Independente (PEI) que podiam ser identificados no Universalismo de Figueiredo. Penna acredita que essas concepçōes acabariam por levar o país a alinhamentos automáticos com a União Soviética. Por tudo isso, ele propõe política externa que promovesse reversão aos padrões de Castelo Branco, ancorada nos princípios da Segurança e do Desenvolvimento. Para tanto, o país deveria alinhar-se com os países ocidentais do Primeiro Mundo, com os quais estaria ligado por interesses culturais, políticos e econômicos. Tal união garantiria a sobrevivência do Brasil como um país livre, próspero e democrático (DIGESTO, 1982, abril, p. 120).

José Pedro Galvão de Souza (DIGESTO, 1982, setembro, p. 49) também estava em desacordo com a política externa do general Figueiredo. Em palestra na Associação Comercial de São Paulo, analisou que o processo político em curso no país trazia custosos retrocessos tanto à política interna quanto à externa. Para ele, o país retrocedera aos anos anteriores a 1964. No plano externo, ele julgava que o dito pragmatismo responsável fazia recordar o neutralismo positivo e a política da independência. Portanto, a lógica do raciocínio de Souza comungava com Penna o suposto de que a política externa era parte do universo político interno e dele derivava. Sendo assim, propunha a reversão da política para aquela marcada pela 'fronteira ideológica'.

Manoel Pio Correa Junior (DIGESTO, 1984, março/abril, p.41), invocando o "saudoso presidente Castelo Branco", argumentava que a política 
externa afetava toda a nação e tinha a particular característica de admitir menos oscilações em sua condução. Neste sentido, criticava os erros da política externa do governo Figueiredo. Segundo ele, o terceiro-mundismo está baseado na falácia da divisão arbitrária e perigosa que acaba por arrastar o Brasil para alinhamentos inconvenientes e descabidos, podendo levar ao conflito nortesul. Tal divisão horizontal seria caricata, pois colocava países como Haiti e alguns países africanos notadamente miseráveis no hemisfério norte, enquanto Brasil, Argentina, África do Sul, Austrália e Nova Zelândia (países emergente, em avançado estágio de industrialização) eram colocados no hemisfério sul. Em sua opinião já era tempo de posicionar o Brasil corretamente no contexto internacional, "devolvendo-lhe a sua digna posição, da qual por vezes parece levado a querer abdicar: uma posição fora do Terceiro Mundo, em companhia dos países dos mais adiantado grau de civilização".

Tais posições discordantes da Política Externa Universalista não são fatos isolados. Antes, aparecem e se consolidam em importantes setores da sociedade brasileira. A dimensão das críticas pode ser comprovada pela necessidade de reação do governo. Em exposição na Comissão de Relações Exteriores do Senado (RESENHA, 21.9.1983, p. 41), em 21 de setembro de 1983, Guerreiro defende a política externa de sua gestão. Para ele, os posicionamentos excludentes pregados pelos críticos podiam até trazer alguma tranqüilidade para o país no curto prazo. Entretanto, por serem posições que não refletiam a realidade brasileira, suas conseqüências seriam desastrosas. Guerreiro argumentava que a realidade impunha um posicionamento brasileiro no cenário internacional que contemplasse ao mesmo tempo sua condição de país ocidental e do Terceiro Mundo. Neste sentido, idéias que pregavam que o Brasil deveria escolher somente umas das possibilidades deveriam ser combatidas. Ele acreditava que a política externa não deveria, necessariamente, optar entre uma delas para ganhar consistência.

Fica explícito, no discurso de Guerreiro, que o consenso do interesse nacional estava em risco, sofrendo crescentes e contundentes questionamentos como os apontados acima. Assim, o chanceler continua a defender o Universalismo e busca demonstrar o prejuízo para o país caso adotássemos qualquer linha política excludente. Guerreiro acreditava na necessidade de se efetivar a conciliação das vertentes ocidental e de Terceiro Mundo vividas pelo Brasil.

Uns dirão que somos terceiro-mundistas, que transformamos o que era condição em postura ideológica. Imaginarão um suposto desbalanceamento - um desequilíbrio para melhor poderem aconselhar aproximações em sentido radicalmente oposto, em busca de uma espécie de exclusivismo ou forte preferência ocidentalista em nossa política. Denunciarão supostas simpatias pelo Segundo Mundo, o que não passa, evidentemente, de simples artifício retórico ou insinuação malévola. Por outro lado, vindas de outros quadrantes, haverá acusações de que não aderimos ao que seria o ideal terceiro-mundista. Nem uns, nem outros, tem razão. Somos o que somos. Um 
país com identidade própria e ligações variadas, mas definidas a partir dessa identidade (RESENHA, 21.9.1983, p. 43).

Guerreiro (RESENHA, 21.9.1983, p. 41) considera que não há qualquer exclusivismo de contatos ou ideologia que informe a escolha dos parceiros comerciais do país. "Ao contrário, temos sido rigorosamente fiéis ao postulado do Universalismo, não apenas por que seja boa doutrina, mas simplesmente porque a complexidade da cena internacional o exige e porque as necessidades e os interesses brasileiros o aconselham". Adiante, o chanceler pondera sobre o tipo de vantagem que o Brasil conseguiria se assumisse alinhamento exclusivista e excludente que marcadamente privilegiasse os contatos com o Ocidente desenvolvido. Guerreiro (idem, p. 48) estava convencido de que tal postura não resolveria automaticamente as questões políticas e as dificuldades econômicas.

Do ponto de vista financeiro, Guerreiro defende que a postura brasileira de proximidade com o Terceiro Mundo não trazia penalidades ao país. Comercialmente, idem. Portanto, não haveria vantagem em abandonar os mercados conquistados em decorrência de dificuldades conjunturais. Em sua concepção, alinhamentos rígidos aumentam a fragilidade do mais fraco. Portanto, não deveria o Governo Figueiredo descaracterizar a nação na tentativa de se obter falsas seguranças baseadas na generosidade alheia. Em socorro de seu argumento, Guerreiro (idem, p. 48) invocava Ruy Barbosa para ditar a forma de comportamento correto do Brasil no cenário internacional: o Brasil precisa ser digno de si para que mereça a amizade e o respeito de seus parceiros internacionais.

Guerreiro (RESENHA, 1983, p. 50) argumentava que o Brasil deixaria de comerciar com o mundo inteiro se a ação externa brasileira seguisse o raciocínio de seus críticos e fosse orientada pelas flutuações de curto prazo, reduzindo-se os contatos com aqueles países que preterissem produtos brasileiros. Para comprovar seu ponto, ele demonstrava que as exportaçóes para o Terceiro Mundo eram responsáveis por mais de um milhão de empregos no Brasil e vinham sendo pagas regularmente.

Continua o chanceler (idem, p. 56) dizendo que o raciocínio de seus críticos é um sofisma, pois parte do pressuposto da existência de opções de mercado para o Brasil. De modo diverso, países sedentos por crescentes superávits comerciais não podem se dar ao luxo de escolher com quem comerciar. Complementarmente, ele considerava que o Brasil não poderia possuir relações externas unidimensionais, somente em busca de dinheiro e mercados, pois a boa política externa deve levar em consideração preocupações políticas, humanas e de segurança. Portanto, Guerreiro combatia aqueles que se deixavam levar por slogans ou se iludiam por visóes reducionistas da realidade.

Finalmente, o chanceler aponta os equívocos das propostas alternativas. Havia, em sua visão, duas principais: uma que defendia as vantagens absolutas 
do processo e outra que advogava a não necessidade de rearranjo nas estruturas internacionais, por imaginar ser esse um fenômeno menor. Para Guerreiro (RESENHA, 1.8.1983, p. 19) ambas as posturas eram equivocadas, pois diante da crise que se vivia e da interdependência imposta pela conjuntura, economia e política se mesclavam de tal modo que passavam muitas vezes por verdadeiramente indistinguíveis. Por tal motivo, ele defende a adequação dos mecanismos políticos internacionais, pois "a dinâmica da economia se tornou muito mais rápida do que a capacidade política de atendê-la e, sobretudo, gerenciá-la equitativamente” (idem, p. 21).

Finalmente, resta claro o rico e intenso debate acerca da política externa que se travou na gestão do general João Baptista de Oliveira Figueiredo. A emergência de descontentes com a política em curso foi fato demonstrado aqui. Antes de vozes unívocas, o período marcou-se pela composição de grupos distintos a defenderem idéias opostas. Fatos que ditaram a ruína do consenso na PEB.

\section{Conclusão}

Idéias preestabelecidas sobre períodos históricos pouco estudados não são boas guias para o analista. No mínimo, exigem cuidados, olhar desconfiado. O Universalismo do General Figueiredo é considerado uma continuidade do 'Pragmatismo Responsável' de Geisel. Mas as ações da diplomacia gerenciada pelo chanceler Guerreiro até hoje receberam pouca atenção (VIZENTINI, 1998, p. 271). Tal carência instiga dúvidas. Assim, embora tenham sido identificados elementos de continuidade nessa política, especificidades puderam ser observadas mediante outras variáveis da formulação da política externa do período (SILVA, 1995).

Pela coleta de fontes que expressavam as idéias defendidas por diferentes atores influentes na formulação e execução da política externa, demonstrou-se que o Universalismo não foi o único projeto de inserção internacional brasileiro a ganhar voz na gestão do último general presidente do ciclo militar iniciado no golpe militar de 1964. Assim, apesar da existência de um chamamento ao consenso para a fixação do Interesse Nacional, a conjuntura impediu a existência de somente uma matriz propositiva para a inserção externa da nação. Por meio das críticas aos pressupostos do Universalismo, evidenciou-se o dissenso no interior das estruturas burocráticas o Estado brasileiro.

Ao se proceder tal análise, firmou-se a pertinência da utilização de teoria que concebe o Estado como permeável ao jogo político, e não como estrutura monolítica que age verticalmente impondo ações no corpo social (PINHEIRO, 1994). Portanto, a burocracia estatal é analisada em sua complexidade, tomada como estrutura que abriga em seu interior grupos de pressão com múltiplas idéias e interesses na luta pelo poder. Neste sentido, ressaltou-se o fato de o 
período de Abertura política ter contribuído para redimensionar a autonomia do Itamaraty em relação ao aparelho do Estado através do questionamento de seu raio de ação por setores descontentes no interior da própria burocracia.

Para que se aclarassem as causas da emergência de vozes descontentes com as políticas oficiais, pode-se apontar a conjuntura crítica vivida pelo governo Figueiredo que levou ao esgotamento do modelo de desenvolvimento por substituição de importações, baseado em forte atuação 'empresarial' do Estado e financiado por capitais externos. Outro limite foi dado pela conjuntura econômica internacional que causou fortes constrangimentos à economia brasileira. Conjugou-se a tais fatos adversos do campo econômico, o processo de Abertura política conduzido pelo governo que também implicava redistribuição de poderes na sociedade. Tal conjuntura tornou possível o dissenso, tanto por parte da oposição, como por atores que anteriormente compunham a aliança legitimadora do governo militar.

Ao se retratar a economia política da redemocratização e seu impacto para a estrutura governamental, evidenciou-se a existência do debate entre diferentes projetos para a melhor inserção internacional do Brasil. Tais concepções eram decorrentes da percepção que os diferentes grupos possuíam da conjuntura e do papel que o país deveria assumir no sistema internacional. Assim, foram vencedores aqueles setores do Itamaraty que propugnavam pela necessidade de o Brasil posicionar-se no debate norte-sul assumindo os reclames dos países sub e em desenvolvimento. O discurso dos executores da política externa de Figueiredo notabilizou-se por apontar as injustiças do sistema internacional e as mazelas vividas pelos países que viam seus projetos serem travados pela impossibilidade de aquisição de insumos ao desenvolvimento. Culpa era atribuída ao comportamento autoritário dos países desenvolvidos no sistema internacional. Por isso, o Itamaraty defendia que novas instituiçóes deveriam ser criadas no intuito de se desobstruírem os canais de negociação entre países do norte e do sul. Neste sentido, o governo brasileiro procurou utilizar o tema da abertura política interna para, no âmbito externo, reclamar maior democracia para a comunidade internacional.

O Universalismo ainda abrigava a concepção do Brasil como país vivendo entre dois mundos. Possuía características do Primeiro e do Terceiro Mundo. Por isso, Guerreiro sempre defendia que a postura do Brasil no mundo não era questão de escolha, mas imposta pela especificidade do país. Mas, a aproximação com o Terceiro Mundo não deveria significar o abandono ou o desprezo em relação às relaçóes com o Primeiro Mundo. O chanceler justificava a ampliação dos contatos diplomáticos pela necessidade de novos mercados para os produtos brasileiros, mas procurava revestir tal argumento com ancestrais princípios da diplomacia brasileira, como aquele que defendia que nem tudo se resumia à economia.

No entanto, apesar de ser a política oficial, o Universalismo não se estabeleceu em bases consensuais. Em contraste com tal matriz globalizante 
que pregava postura de maior autonomia em relação aos centros de poder do norte (marcadamente em relação aos norte-americanos), estabeleceu-se um grupo de atores que propunham novos rumos para as relações internacionais do país. Acusava-se o Universalismo de ser 'terceiromundista', postura que havia transformado condição real em posicionamento ideológico para a ação externa do país. Ainda, defendia-se que a aproximação com os países do chamado Segundo Mundo não traria ganhos efetivos para o país.

Roberto de Oliveira Campos foi um expoente dos setores críticos ao Universalismo. Suas palavras deixavam claro o descontentamento com as opções da PEB de Figueiredo. Assim, seu receituário indicava a reversão da postura terceiromundista, arredia às influências inevitáveis dos centros de poder ocidental, rumo à constituição de quadro de hierarquização dos contatos diplomáticos do país. A lógica proposta ditava a constituição de quadro de relações que otimizassem a performance, retirando-se todo o enlevo político reivindicatório existente no Universalismo.

Meira Penna, ex-embaixador brasileiro na Polônia, tecia ácidas críticas ao Universalismo. Ele considerava inadmissível a aproximação com países cuja ideologia não era compatível com a história ocidental brasileira. Pio Corrêa Junior e Galvão de Souza também ajudavam a engrossar o coro dos descontentes. Suas falas combatiam os pressupostos que pregavam a busca indiscriminada de mercados pelo mundo afora. Antes, pregavam-se lógicas seletivas, como os 'círculos concêntricos', as opções ideológicas e 'parcerias seletivas' como guias da PEB.

De resto, observe-se que tais críticas causaram tanto incômodo ao governo que o próprio ministro das Relações Exteriores veio a público defender as ações que vinham sendo tomadas em sua gestão. Fato invulgar nos regimes militares.

Recebido em 20 de setembro de 2006 Aprovado em 10 de novembro de 2006

\section{Referências bibliográficas}

CAMPOS, Roberto de Oliveira. A Lanterna na Popa: Memórias. RJ: Topbooks, 1994.

CERVO, Amado Luiz \& BUENO, Clodoaldo. História da Política Externa do Brasil. Brasília: Ed. UnB, 2002.

DEBRUM, Michel. A conciliação e outras estratégias. SP: Brasiliense, 1983.

GUERREIRO, Ramiro Saraiva. Lembranças de um funcionário do Itamaraty. São Paulo: Siciliano, 1992.

HIRST, Mônica(org.). Brasil-Estados Unidos na transição democrática. RJ: Paz e Terra, 1985.

LAFER, Celso. Paradoxos e Possibilidades, RJ: Nova Fronteira, 1982. 
MILZA, Pierre. Politica interna e política externa. In: REMOND, René (org.). Por uma história política. RJ: UFRJ e Edit. FGV, 1996.

PRZEWORSKI, Adam. Democracia e mercado: reformas politicas e econômicas no Leste Europeu e na América Latina. Rio de Janeiro: Relumé-Dumará, 1994.

RODRIGUES, José Honório Rodrigues. Interesse Nacional e Politica Externa. Rio de Janeiro: Paz e Terra, 1966.

SKIDMORE, Thomas. Brasil: de Castelo a Tancredo (1964-1985). Rio de Janeiro: Paz e Terra, 1988.

SKIDMORE, Thomas. The Politics of Military Rule in Brazil, 1964-1985. Oxford University Press; Reprint edition (March 1, 1990).

TEIXEIRA, Ivana Pedroso. O Universalismo diante da possibilidade Européia. A política externa do governo Figueiredo (1979-1985). Itajaí: Univali, 2002.

VIZENTINI, Paulo. A política externa do regime militar brasileiro: multilateralização, desenvolvimento e a construção de uma potência média (1964-1985). Porto Alegre: Ed. UFRGS, 1998.

\section{Artigos científicos}

CERVO, Luis Amado. In: Revista Brasileira de Política Internacional, n.46/2, 2003, pp.13-39.

SILVA, Alexandra de Mello. O Brasil no Continente e no Mundo: atores e imagens na política externa contemporânea. In Estudos Históricos, n.15. 1995/1.

\section{Teses e dissertações}

PINHEIRO, Letícia de Abreu. Foreign Policy decision making under the Geisel government: the President, the military and the foreign ministry. Thesis submitted for the Degree of PH.D. of International Relations, London School of Economics and Political Science. Mimeo, 1994.

\section{Fontes primárias}

Resenha da Política Exterior do Brasil (de 1979 a 1985). (Aqui referida como RESENHA). A Palavra do Brasil nas Nações Unidas (1946-1995). Brasília: FUNAG/MRE, 1996.

CAMPOS, Roberto de Oliveira. Novas Perspectivas da Política Externa Brasileira (19791985). 1978. CPDOC, Fundo ASS. MRE ag. 1978.08.30 / Série MRE. MRE/ Sub-série. Assuntos Gerais/ Produção 30.08.1978 a 06.03.1979. Memorando de Roberto de Oliveira Campos para o Ministro das Relaçôes Exteriores do governo Geisel, Azeredo da Silveira.

(Aqui referido como NPPEB)

\section{Material imprensa}

Revista ISTO É

Revista VEJA

Revista VISÃO

Revista Digesto Econômico (Aqui referido como DIGESTO) 
TÚLIO SÉRgio HenRIQUes FerReIRA

\section{Resumo}

Neste artigo se analisa a política externa do Brasil na gestão do general João Baptista de Oliveira Figueiredo, último presidente do ciclo militar iniciado com o Golpe de 1964. O Brasil viveu, neste período, processo de abertura política e de recondução do país ao regime democrático. Neste contexto, a Política Exterior da nação - conhecida por parte da historiografia como Universalismo - caracterizou-se pela aproximação comercial com diversos países nos quatro cantos do mundo e pelo discurso de denúncia das desigualdades existentes no sistema internacional. Entretanto, devido à crise manifestada, no período, em várias dimensões da vida nacional, o Universalismo não se estabeleceu em bases consensuais no aparato burocrático do Estado brasileiro. Houve claras manifestações de descontentamento em relação àquela política externa capitaneada pelo chanceler Ramiro Saraiva Guerreiro. Assim, o argumento centra-se na discussão e demonstração do contraste entre o Universalismo e seus críticos, buscando contribuir para o melhor detalhamento da política exterior do Brasil.

\section{Abstract}

This paper analyzes the Brazilian foreign policy under General João Baptista de Oliveira Figueiredo, the last President of the military cycle started by the coup d'etat of 1964 During his presidency, Brazil went through a process of redemocratization. In this context, the Brazilian Foreign Policy became known, by part of the historiography, as 'Universalismo'. Such policy had the expansion of contacts throughout the world as one of its main characteristics and produced discourse to denounce the 'unfair' international system. Nevertheless, because of the great crisis that occurred in multiple aspects of the country, 'Universalismo' didn't establish itself as a consensus inside the Brazilian bureaucratic apparatus. There were evident manifestations against that governmental Foreign Policy leaded by the Foreign Ministry Ramiro Saraiva Guerreiro. Hence the central argument is to discuss and demonstrate the contrast between 'Universalismo' and its critics. Finally, the paper seeks to better detail the Brazilian foreign policy.

Palavras-chave: Política externa brasileira, Governo Figueiredo, Universalismo, Saraiva Guerreiro, Roberto Campos.

Key words: Brazilian foreign policy, Figueiredo government. 